\title{
PENGARUH INTERNAL PERUSAHAAN, EKSTERNAL AUDIT, DAN KOMITE AUDIT TERHADAP AUDIT DELAY DI PERUSAHAAN GO PUBLIC DI INDONESIA
}

\author{
Fauziah Wahyuning Tias \\ Ni Nyoman Alit Triani \\ Fakultas Ekonomi Universitas Negeri Surabaya \\ trianialit8@gmail.com
}

Abstract

Audit delay is the time difference between the date of the financial statements and independent auditor's report. This study aims to identify and analyze whether the debt-to-equity ratio (DER), gain or loss suffered by the company, the size of the firm, the auditor's opinion, the size of the audit committee and the number of audit committee meetings to audit delay in the manufacturing companies listed on the Indonesian Stock Exchange. The sampling technique used in this study was purposive sampling and obtained a sample of 31 companies. This research was conducted in the period 2008 to 2012. The data used are the financial statements, annual reports and ICMD. Multiple regression method is used to prove the hypothesis. Testing in this study using SPSS version 21. The results of this study indicate that the debt-to-equity ratio (DER), gain or loss suffered by the company, the size of the firm, the auditor's opinion, the size of the audit committee and the number of audit committee meetings simultaneously affect the audit delay. Partially, the audit opinion affect the audit delay. Other variables such as the debt-to-equity ratio (DER), gain or loss suffered by the company, the size of the firm, the size of the audit committee and the number of audit committee meetings does not affect the audit delay.

Keywords: internal audit, external audit, audit committee, the audit pelay 
Abstrak

Audit delay adalah perbedaan waktu antara tanggal laporan keuangan dan tanggal laporan auditor independen. Penelitian ini bertujuan untuk mengetahui dan menganalisis apakah Debt to Equity Ratio (DER), laba atau rugi yang dialami perusahaan, ukuran KAP, opini auditor, ukuran komite audit dan jumlah pertemuan komite audit terhadap audit delay pada perusahaan manufaktur yang terdaftar di Bursa Efek Indonesia. Teknik pengambilan sampel yang digunakan dalam penelitian ini adalah purposive sampling dan diperoleh sampel sebanyak 31 perusahaan. Penelitian ini dilakukan pada periode 2008 sampai dengan 2012. Data yang digunakan adalah laporan keuangan, laporan tahunan dan ICMD. Metode regresi berganda digunakan untuk membuktikan hipotesis. Pengujian dalam penelitian ini menggunakan SPPS versi 21. Hasil dari penelitian ini menunjukkan bahwa Debt to Equity Ratio (DER), laba atau rugi yang dialami perusahaan, ukuran KAP, opini auditor, ukuran komite audit dan jumlah pertemuan komite audit secara simultan berpengaruh terhadap audit delay. Secara parsial, opini audit berpengaruh terhadap audit delay. Variabel lain seperti Debt to Equity Ratio (DER), laba atau rugi yang dialami perusahaan, ukuran KAP, ukuran komite audit dan jumlah pertemuan komite audit tidak berpengaruh terhadap audit delay.

Kata kunci: internal audit, eksternal audit, audit pelay

\section{PENDAHULUAN}

Skandal keuangan banyak terjadi di dunia. Tercatat 51 perusahaan terlibat dalam skandal keuangan sejak tahun 1980 hingga 2010. Perusahaan tersebut lebih banyak tersebar di Amerika Serikat, sedangkan perusahaan yang lain berada di wilayah Inggris, Australia, Italia, dan Luksemburg (Tuanakotta, 2011:184). Skandal keuangan di Indonesia juga pernah dialami oleh PT Kimia Farma Tbk. Berdasarkan siaran pers BAPEPAM-LK (Badan Pengawas Pasar Modal dan Laporan Keuangan) tanggal 27 Desember 2002, telah diumumkan bahwa PT Kimia Farma terbukti melakukan kesalahan dalam penyajian dalam laporan keuangan (BAPEPAM-LK, 2002). Dampak kesalahan tersebut mengakibatkan overstated laba pada laba bersih untuk tahun yang berakhir 31 Desember 2001 sebesar Rp 32,7 miliar yang merupakan 2,3\% dari penjualan dan 24,7\% dari laba bersih PT Kimia Farma Tbk. Investor dirugikan dengan skandal ini karena laba yang overstated telah dijadikan dasar transaksi oleh para investor untuk berbisnis (Sabeni, 2005).

Laporan keuangan merupakan media komunikasi antara pihak internal perusahaan dengan pihak eksternal dan bentuk pertanggungjawaban manajemen kepada pemilik saham sebagai dasar dalam pengambilan keputusan. Apabila laporan tersebut mengandung salah saji yang material, maka pihak eksternal yang menggunakan laporan keuangan sebagai dasar pengambilan keputusan akan dirugikan. Audit 
dirancang untuk memberikan keyakinan bahwa laporan keuangan tidak dipengaruhi oleh salah saji (misstatement) yang material dan juga memberikan keyakinan yang memadai atas akuntabilitas manajemen perusahaan (Koroy, 2008).

Perusahaan yang sudah go public diwajibkan untuk menyerahkan laporan keuangan auditan. Hal ini diatur dalam peraturan BAPEPAM-LK X.E.1 tahun 2008 bahwa laporan keuangan tahunan harus disertai laporan akuntan dengan pendapat yang lazim serta disampaikan kepada BAPEPAM-LK selambat-lambatnya pada akhir bulan ketiga setelah tanggal laporan keuangan.Berdasarkan peraturan tersebut, dapat disimpulkan bahwa laporan keuangan yang disampaika kepada BAPEPAM-LK harus disertai dengan laporan audit.

Laporan audit merupakan hasil akhir dari proses audit. Untuk menyelesaikan laporan audit, auditor tentu memerlukan waktu. Lama auditor menyelesaikan laporan audit (audit delay atau audit report lag) diukur dari tanggal laporan keuangan hingga tanggal laporan audit (Ashton, et al., 1987; Hossain dan Taylor, 1998; Lambert et al., 2007; Asthana, 2012). Semakin lama audit delay, maka semakin besar pula kemungkinan keterlambatan penyampaian laporan keuangan ke BAPEPAM-LK. Apabila terjadi penundaan yang tidak semestinya dalam pelaporan, maka informasi yang dihasilkan akan kehilagan relevansinya (IAI, 2012 paragraf 43). Relevansi merupakan salah satu karakteristik kualitatif laporan keuangan selain dapat dipahami, keandalan dan dapat dibandingkan.

Shukeri dan Nelson (2011) meneliti pengaruh board independence, ukuran komite audit, audit committe meeting (jumlah pertemuan komite audit), kualifikasi komite audit, ukuran KAP, opini auditor, dan performa perusahaan terhadap audit delay menemukan bahwa ukuran KAP, opini auditor, dan performa perusahaan terhadap audit delay.

Asthana (2012) menemukan bukti empiris bahwa current ratio, ukuran perusahaan, kerugian perusahaan, financial distress, rasio persediaan, segmen perusahaan, kontijensi, KAP big4, audit tenure, opini auditor, lokasi dimana KAP yang digunakan berada, dan busy season berpengaruh terhadap audit delay. Ika dan Ghazali (2012) menemukan bahwa ketepatan waktu laporan keuangan terkait dengan evektifitas komite audit.

Penelitian ini akan mengkaji faktor-faktor yang mempengaruhi audit delay. $D E R$ dan Rugi atau laba yang dialami perusahaan berasal dari internal perusahaan, opini auditor dan kualitas KAP berasal dari auditor eksternal, ukuran dan komite audit dan audit committe meeting berasal dari komite audit. DER (Debt to Equity Ratio) merupakan salah satu faktor yang dapat mempengaruhi. Ce-Ahmad dan Abidin (2008) menemukan pengaruh DER terhadap audit delay.

Rugi atau laba yang dialami perusahaan menjadi salah satu faktor yang mempengaruhi audit delay. Caslaw dan Kaplan (1991), Utami (2006), dan Asthana (2012) menemukan bukti empiris bahwa pengumuman kerugian perusahaan berpengaruh terhadap masa audit delay yang lebih panjang. Salah satu penjelasan yang masuk 
akal mengapa perusahaan yang rugi memerlukan waktu lebih lama untuk menyajikan laporan keuangan adalah karena peruahaan dengan kondisi keuangan yang lemah menimbulkan resiko audit yang lebih besar (Jaggi dan Tsui, 1999). .

Ukuran KAP juga dianggap dapat mempengaruhi audit delay. Auditor yang dianggap memiliki ukuran bagus adalah BIG4. Ashton, et al. (1987), Schwartz dan Soo (1996) dalam Utami (2006), dan Asthana (2012) membuktikan bahwa perusahaan yang daiudit oleh KAP afiliasi internasional (KAP Big Four) cenderung lebih cepat dalam menyelesaikan laporan keuangan auditannya sehingga perusahaan dapat lebih cepat dalam menyampaikan laporan keuangan auditan.

Subekti dan Widiyanti (2004) menemukan bukti empiris bahwa pemberian qualified opinion berdampak pada lamanya penyelesaian audit yang lebih lama dan penyampaian laporan keuangan auditan yang lebih lama. Namun, Carslaw dan Kaplan (1991), Hossain dan Taylor (1998) tidak berhasil menemukan pengaruh pemberian opini auditor terhadap lamanya penyelesaian audit.

Ukuran komite audit merupakan jumlah anggota dalam komite audit. MohamadNor, et al. (2010), Ika dan Ghazali (2012), Shukeri dan Islam (2012) menemukan pengaruh ukuran komite audit terhadap lamanya audit delay. Perusahaan yang mempunyai komite audit lebih cepat dalam melakukan proses auditnya karena diduga mempunyai sistem pengendalian intern yang baik sehingga memudahkan tugas auditor dalam proses audit atas laporan keuangan klien (Mumpuni, 2011).

Audit committe meeting adalah tempat bagi direksi untuk membahas proses pelaporan keuangan dan juga sebagai monitoring pelaporan keuangan terjadi (Menon dan Williams, 1994 dalam Mohamad-Nor, et al., 2010). Mohamad-Nor, et al. (2010), Ika dan Ghazali (2012), Shukeri dan Islam (2012) menemukan pengaruh pertemuan komite audit dengan lamanya audit delay.

Penelitian ini mengacu pada penelitian Shukeri dan Islam (2012) yang dilakukan di Malaysia. Variabel independen yang digunakan adalah board independece, kualifikasi komite audit, ukuran komite audit dan jumlah pertemuan komite audit. Variabel kontrol yang digunakan adalah ukuran KAP, opini auditor, total aset, dan performa perusahaan. Variabel tersebut diuji pengaruhnya terhadap audit delay. Variabel yang berpengaruh adalah ukuran komite audit, jumlah pertemuan komite audit, ukuran KAP, opini auditor, total aset, dan performa peruahaan yang dilihat dari rugi atau laba yang dialami perusahaan. Sampel yang digunakan dalam penelitian ini adalah perusahaan manufaktur.

Kecendrungan perusahaan yang melakukan audit delaya dalam kurun waktu 2008-2012 yang paling sering melakukan audit delay adalah yang ditunjukkan dalam grafik di bawah ini: 


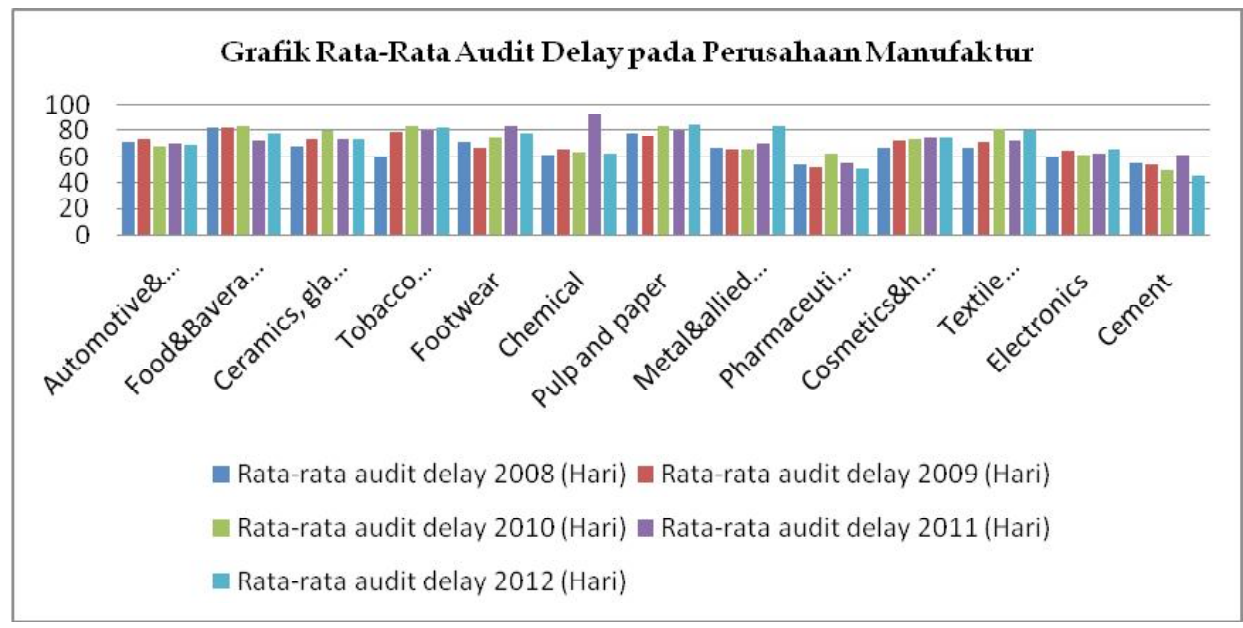

\section{Grafik 1. Rata-Rata Audit Delay pada Perusahaan Manufaktur}

Sumber: data diolah

\section{Rumusan Masalah}

Dari latar belakang diatas, rumusan masalah yang diusulkan adalah sebagai beriikut:

1. Apakah $D E R$, rugi atau laba perusahaan, ukuran KAP, opini auditor ukuran komite audit dan audit committe meeting secara simultan berpengaruh terhadap audit delay?

2. Apakah $D E R$, rugi atau laba perusahaan, ukuran KAP, opini auditor ukuran komite audit dan audit committe meeting secara parsial berpengaruh terhadap audit delay?

\section{TINJAUAN PUSTAKA}

\section{Audit Delay}

Ashtana (2012) mendefinisikan audit delay sebagai lamanya waktu dari tanggal akhir tahun fiskal perusahaan dengan tanggal laporan auditor. Berbagai penelitian (Ashton, et al., 1987; Hossain dan Taylor, 1998; Lee dan Jahng, 2008; Mohamad et al., 2012; Wan-Hussin daan Bamahros, 2012) juga mendefiniskan audit delay sebagai lamanya waktu antara tanggal laporan keuangan tahunan dengan tanggal laporan audit.

Lamanya audit delay akan mempengaruhi ketepatan perusahaan dalam menyampaikan laporan keuangan ke BAPEPAM-LK. Tuntutan akan kepatuhan terhadap ketepatan waktu (timeliness) dalam penyajian laporan keuangan kepada perusahaan di Indonesia diatur dalam peraturan BAPEPAM-LK-LK X.E.1 tahun 2008 bahwa Laporam Keuangan Tahunan Harus disertai dengan laporan Akuntan dengan pendapat yang lazim serta disampaikan kepada BAPEPAM-LK-LK selambat- 
lambatnya pada akhir bulan ke-3 (ketiga) setelah tanggal Laporan Keuangan Tahunan.

\section{Hipotesis Penelitian}

Hipotesis yang diusulkan dalam penelitian ini adalah sebagai berikut:

$\mathrm{H}_{1}$ : DER berpengaruh terhadap audit delay

$\mathrm{H}_{2}$ : Rugi atau laba yang dialami perusahaan berpengaruh terhadap audit delay

$\mathrm{H}_{3}$ : Ukuran KAP berpengaruh terhadap audit delay

$\mathrm{H}_{4}$ : Opini unqualified berpengaruh terhadap audit delay

$\mathrm{H}_{5}$ : Ukuran komite audit berpengaruh terhadap audit delay

$\mathrm{H}_{6}$ : Audit Committe Meeting berpengaruh pada audit delay

\section{METODOLOGI PENELITIAN}

Popolasi dalam penelitian ini adalah seluruh perusahaan yang terdaftar di Bursa Efek Indonesia. Metode pengumpulan sampelnya menggunakan metode purposive sampling. Kriteria yang digunakan adalah perusahaan kelompok manufaktur pada tahun 2008-2012 secara berturut-turut. Alasan lain menggunakan perushaan manufaktur sebagai objek penelitian adalah karena perusahaan memiliki kompleksitas operasi yang lebih tinggi dibandingkan dengan perusahaan finansial.

Tabel 1. Metode Pengumpulan Sampel

\begin{tabular}{lc}
\hline \multicolumn{1}{c}{ Keterangan } & \\
\hline Perushaan Manufaktur yang Berturut-Turut pada Tahun 2008-2012 & 133 \\
Tidak menyampaikan laporan keuangan dan laporan tahunan secara berturut-turut & $(71)$ \\
selama 5 Tahun & $(13)$ \\
Tidak ada laporan audit & $(9)$ \\
Mata uang asing & $(9)$ \\
Tidak menyediakan data dengan lengkap terkait dengan variabel yang digunakan \\
Total sampel
\end{tabular}

Sumber: www.idx.co.id

\section{Definisi Operasional}

\section{Audit delay}

Audit delay, yaitu jangka waktu anatara tanggal akhir tahun perusahaan dengan tanggal laporan audit (Ashton, et al., 1987). Variabel ini diukur secara kuantitatif dalam jumlah hari. 


\section{Debt to Equity RatioI (DER)}

DER merupakan salah satu rasio pengukur laverage (penggunaan utang). Semakin tinggi proporsi DER, maka semakin besar resiko keuangan bagi kreditor maupun pemegang saham. Rasio debt to equity ratio dihitung dengan rumusan sebagai berikut:

$D E R=\frac{\text { Total Kewajiban }}{\text { Total Ekuitas }} \times 100 \%$

\section{Laba atau Rugi yang Dialami Perusahaan}

Pengukuran variabel kerugian yang dialami perusahaan pada masing-masing tahun merupakan variabel dummy. Perusahaan yang mengalami rugi diberi angka satu (1) dan yang mengalami laba angka nol (0).

\section{Ukuran KAP}

Ukuran KAP (Kantor Akuntan Publik) dalam penelitian ini melihat apakah KAP berafilisas Asing big 4. Ukuran KAP diukur dengan dummy, 1 jika KAP berafiliasi Asing Big 4, dan nol (0) yang lainnya.

\section{Opini Auditor}

Opini auditor dalam penelitian hanya memfokuskan pada opini unqulified. Opini auditor disini diukur dengan dummy 1 jika opni unquailfied dan nol (0) lainnya.

\section{Jumlah Komite Audit}

Peraturan BAPEPAM-LK No. Kep-29/PM/2004 menyatakan bahwa komite audit terdiri dari sekurang-kurangnya satu orang komisaris independen dan sekurangkurangnya dua orang anggota lainnya berasal dari luar emiten atau perusahaan publik. Variabel ukuran komite audit dalam penelitian ini diukur denngan jumlah anggota di dalam komite audit.

\section{Audit Committe Meeting}

Peraturan BAPEPAM Nomor IX.1.5 yang tertuang dalam Keputuan Ketua BAPEPAM No. Kep-29/PM/2004 tanggal 24 September 2004 menyatakan bahwa jumlah pertemuan atau rapat yang dilakukan oleh komite audit sekurang-kurangnya sama dengan ketentuan minimal Dewan Komisaris atas setiap penugasan yang ditetapkan dalam Anggaran Dasar. Selain itu pedoman FCGI (2002) menegaskan bahwa komite audit harus mengadakan pertemuan paling sedikit setiap tiga bulan atau minimal empat kali pertemuan dalam satu tahun. Variabel frekuensi pertemuan komite audit dalam penelitian ini diukur dengan melihat jumlah pertemuan komite audit dalam satu tahun. 


\section{Metode Analisis}

Pengujian hipotesis pada penelitian ini dilakukan dengan menggunakan analisis regresi linier berganda.

$\mathrm{AUDLAY}=\alpha+\beta_{1} D E R+\beta_{2} L O S S+\beta_{3} A U D+\beta_{4} O P I N I+\beta_{5} A C S I Z E+\beta_{6} A C M E E T+\varepsilon$

Keterangan:
AUDLAY = Audit delay
DER
= Debt to Equity Ratio
LOSS = Laba/Rugi yang dialami perusahaan
AUD = Ukuran KAP (Kantor Akuntan Publik)
OPINI = Opini auditor
ACSIZE = Ukuran Komite audit
ACMEET = Audit Committe Meeting (Jumlah pertemuan komite audit)

\section{Statistik Deskriptif}

\begin{tabular}{|l|r|r|r|r|r|}
\hline \multicolumn{7}{|c|}{ Descriptive Statistics } \\
\hline & $\mathrm{N}$ & \multicolumn{1}{|c|}{ Minimum } & \multicolumn{1}{c|}{ Maximum } & \multicolumn{1}{c|}{ Mean } & \multicolumn{1}{c|}{ Std. Deviation } \\
\hline AUDLAY & 155 & 31.0 & 147.0 & 72.045 & 15.3772 \\
\hline DER & 155 & .10 & 8.69 & .9294 & .97306 \\
\hline LOSS & 155 & .0 & 1.0 & .929 & .2576 \\
\hline SIZE & 155 & .0 & 1.0 & .568 & .4970 \\
\hline OPINI & 155 & .0 & 1.0 & .948 & .2220 \\
\hline ACSIZE & 155 & 2.0 & 5.0 & 3.058 & .4732 \\
\hline ACMEET & 155 & 1.0 & 41.0 & 5.742 & 5.0141 \\
\hline Valid N (list wise) & 155 & & & & \\
\hline
\end{tabular}

\section{Uji Multikolonieritas}

\begin{tabular}{|c|c|c|c|c|c|c|c|c|c|c|c|c|c|}
\hline \multicolumn{14}{|c|}{ Coefficients ${ }^{a}$} \\
\hline \multirow{2}{*}{\multicolumn{2}{|c|}{ Model }} & \multicolumn{2}{|c|}{$\begin{array}{l}\text { Unstandardized } \\
\text { Coefficients }\end{array}$} & \multirow{2}{*}{\begin{tabular}{|c|}
$\begin{array}{c}\text { Standardiz } \\
\text { ed } \\
\text { Coefficient } \\
\text { s }\end{array}$ \\
Beta
\end{tabular}} & \multirow[t]{2}{*}{$\mathrm{t}$} & \multirow[t]{2}{*}{ Sig. } & \multicolumn{2}{|c|}{$\begin{array}{l}95,0 \% \text { Confidence } \\
\text { In terval for B }\end{array}$} & \multicolumn{3}{|c|}{ Correlations } & \multicolumn{2}{|c|}{$\begin{array}{l}\text { Collinearity } \\
\text { Statistics }\end{array}$} \\
\hline & & B & Std. Error & & & & $\begin{array}{l}\text { Lower } \\
\text { Bound }\end{array}$ & $\begin{array}{l}\text { Upper } \\
\text { Bound }\end{array}$ & $\begin{array}{l}\text { Zero- } \\
\text { order }\end{array}$ & Partial & Part & $\begin{array}{c}\text { Toleran } \\
\text { ce }\end{array}$ & VIF \\
\hline \multirow{7}{*}{1} & $\begin{array}{l}\text { Consta } \\
\text { nt) }\end{array}$ & 96.885 & 9.048 & & 10.708 & .000 & 79.004 & 114.765 & & & & & \\
\hline & DER & 1.313 & 1.206 & .083 & 1.090 & .278 & -1.069 & 3.696 & .111 & .089 & .080 & .923 & 1.084 \\
\hline & LOSS & -.574 & 4.197 & -.011 & -.137 & .891 & -8.868 & 7.719 & -128 & -.011 & -.010 & .872 & 1.147 \\
\hline & SIZE & -3.081 & 2.448 & -.100 & -1.259 & .210 & -7.920 & 1.757 & -198 & -.103 & -.092 & .857 & 1.166 \\
\hline & OPINI & -18.945 & 3.874 & -.376 & -4.891 & .000 & -26.601 & -11.290 & -418 & -.373 & -.358 & .908 & 1.101 \\
\hline & ACSIZE & -2.008 & 2.822 & -.062 & -.712 & .478 & -7.584 & 3.568 & -190 & -.058 & -.052 & .712 & 1.404 \\
\hline & ACM EET & -115 & .271 & -.037 & -.423 & .673 & -650 & .421 & -161 & -.035 & -.031 & .687 & 1.455 \\
\hline
\end{tabular}

a. Dependent Variable: AUDLAY

Uji multikolonieritas bertujuan untuk menguji apakah model regresi ditemukan adanya korelasi antar variabel bebas (independen). Berdasarkan nilai VIF (Varians Inflation Factor) pada setiap variabelnya, dapat diketahui bahwa nilai VIF dari seluruh variabel bebas lebih kecil dari 10 (VIF < 10), dapat dikatakan bahwa tidak terkena multikoliner (tidak ada hubungan antar variabel bebas). 


\section{Uji Autokorelasi}

Tabel 4.10. Uji Autokorelasi

Model Summary ${ }^{b}$

\begin{tabular}{|l|r|r|r|r|r|}
\hline Model & \multicolumn{1}{|c|}{$\mathrm{R}$} & $\mathrm{R}$ Square & $\begin{array}{c}\text { Adjusted } \mathrm{R} \\
\text { Square }\end{array}$ & $\begin{array}{c}\text { Std. Error of the } \\
\text { Estimate }\end{array}$ & Durbin-Watson \\
\hline 1 & $.453^{\mathrm{a}}$ & .205 & .173 & 13.9830 & 1.847 \\
\hline
\end{tabular}

a. Predictors: (Constant), ACMEET, DER, OPINI, LOSS, SIZE, ACSIZE

b. Dependent Variable: AUDLAY

Pada jumlah sampel sebesar 155 perusahaan dan jumlah variabel bebas sebesar enam, maka diketahui bahwa dL sebesar 1,651 dan dU sebesar 1,817. Berdasarkan nilai tersebut dapat diketahui 4-dL sebesar 2,349 dan 4-dU sebesar 2,183. Tabel 4.3 menunjukkan bahwa Durbin Watson tess sebesar 1,847. Hasil tersebut berada didaerah tidak ada autokorelasi yaitu antara 1,817 dan 2,183.

\section{Uji Heteroskedastitas}

\section{Tabel 4.11 Uji Heteroskedastik}

\begin{tabular}{|c|c|c|c|c|c|c|}
\hline \multicolumn{7}{|c|}{ Coefficients ${ }^{\mathrm{a}}$} \\
\hline & & \multicolumn{2}{|c|}{ Unstandardized Coefficients } & \multirow{2}{*}{$\begin{array}{c}\text { Standardized } \\
\text { Coefficients } \\
\text { Beta }\end{array}$} & \multirow[t]{2}{*}{$\mathrm{T}$} & \multirow[t]{2}{*}{ Sig. } \\
\hline & & $\bar{B}$ & Std. Error & & & \\
\hline \multirow{7}{*}{1} & (Con stant) & 19.039 & 5.396 & & 3.528 & .001 \\
\hline & DER & .018 & .719 & .002 & .024 & .981 \\
\hline & LOSS & -3.833 & 2.503 & -.132 & -1.532 & .128 \\
\hline & SIZE & 1.087 & 1.460 & .065 & .744 & .458 \\
\hline & OPINI & -2.358 & 2.310 & -.086 & -1.021 & .309 \\
\hline & ACSIZE & -1.410 & 1.683 & -.080 & -.838 & .403 \\
\hline & ACMEET & .189 & .162 & .114 & 1.170 & .244 \\
\hline
\end{tabular}

a. Dependent Variable: absres

\section{Koefisien Determinasi $\left(\mathbf{R}^{\mathbf{2}}\right)$}

Koefisien determinasi $\left(\mathrm{R}^{2}\right)$ mengukur seberapa jauh kemampuan model dalam menerangkan variasi dependen. Variabel independen dalam model ini mampu menjelaskan $17,9 \%$ dari variabel dependen. Sehingga masih ada variabel-variabel lain diluar model yang mampu menjelaskan fenomena yang ada pada variabel dependen. 


\section{Uji Normalitas}

Tabel 4.13. Uji Normalitas

One-Sample Kol mogorov-Smimov Test

\begin{tabular}{|ll|r|}
\hline & & \multicolumn{1}{|c|}{$\begin{array}{c}\text { Unstandardized } \\
\text { Residual }\end{array}$} \\
\hline $\mathrm{N}$ & Mean & 155 \\
Normal Parametersab & Std. Deviation & .0000000 \\
& Absol ute & .73 .7078906 \\
MostExtremeDifferences & Positive & .074 \\
& Negative & .074 \\
Kolmogorov-SmirnovZ & & -.074 \\
Asymp. Sig. (2-tail ed) & & .922 \\
\hline
\end{tabular}

a. Test distribution is Normal.

b. Calculated from data.

Uji normalitas bertujuan untuk menguji apaka dalam model regresi, variabel pengganggu atau residual memiliki distribusi normal. Pada hasil uji normalitas $(\mathrm{N}=$ 155) menunjukkan bahwa nilai Kolmogorov Smirnov $Z=0,922$ dengan nilai sig $0,363>$ taraf signifikansi (á) 0,05 . Jadi dapat dikatakan bahwa data berdistribusi normal.

\section{Uji F}

\section{Tabel Uji F}

\begin{tabular}{|rl|r|r|r|r|r|}
\hline Model & & Sum of Squares & \multicolumn{1}{|c|}{ Df } & Mean Square & F & Sig. \\
\hline & Regression & 7477.119 & 6 & 1246.186 & 6.374 & $.000^{\circ}$ \\
& Residual & 28937.565 & 148 & 195.524 & & \\
& Total & 36414.684 & 154 & & & \\
\hline
\end{tabular}

a. Dependent Variable: AUDLAY

b. Predictors: (Constant), ACMEET, DER, OPINI, LOSS, SIZE, ACSIZE 


\section{Uji t}

\section{Tabel Ujit}

\begin{tabular}{|c|c|c|c|c|c|c|}
\hline \multirow{3}{*}{\multicolumn{2}{|c|}{ Model }} & \multicolumn{3}{|c|}{ Coefficients $^{a}$} & \multirow{3}{*}{$\mathrm{t}$} & \multirow{3}{*}{ Sig. } \\
\hline & & \multicolumn{2}{|c|}{ Unstandardized Coefficients } & Standardized & & \\
\hline & & $\mathrm{B}$ & Std. Error & Beta & & \\
\hline \multirow{7}{*}{1} & (Constant) & 96.885 & 9.048 & & 10.708 & .000 \\
\hline & DER & 1.313 & 1.206 & .083 & 1.090 & 278 \\
\hline & LOSS & -.574 & 4.197 & -.011 & -.137 & 891 \\
\hline & SIZE & -3.081 & 2.448 & -.100 & -1.259 & 210 \\
\hline & OPINI & -18.945 & 3.874 & -.376 & -4.891 & .000 \\
\hline & ACSIZE & -2.008 & 2.822 & -.062 & -.712 & .478 \\
\hline & ACMEET & -.115 & .271 & -.037 & -.423 & .673 \\
\hline
\end{tabular}

a. Dependent Variable: AUDLAY

\section{Pengaruh DER terhadap Audit Delay}

Variabel Debt to Equity Ratio (DER) tidak berpengaruh terhadap audit delay (AUDLAY) sebab nilai signifikansinya lebih besar dari $0,05(5 \%)$ yaitu 0.265 $(26,5 \%)$. Tingginya DER merupakan cermin bahwa perusahaan tersebut memiliki resiko keuangan yang tinggi. Resiko keuangan yang tinggi mencerminkan bahwa perusahaan tersebut sedang mengalami kesulitan keuangan sehingga akan merusak nama baik perusahaan. Bad news adalah hal yang sebisa mungkin dihindari oleh perusahaan sehingga manajemen cenderung untuk menunda publikasi laporan keuangan auditan. Hasil penelitian ini mendukung hasil penelitian Wening dan Tyas (2001) dan SupriyatiYuliasari yang menyebutkan DER tidak berpengaruh terhadap audit delay.

\section{SIMPULAN}

\section{Pengaruh Laba atau Rugi yang Dialami Perusahaan terhadap Audit Delay}

Variabel rugi atau laba yang dialami perusahaan (LOSS) tidak berpengaruh terhadap audit delay (AUDLAY). Laba atau rugi yang dialami perusahaan tidak berpengaruh terhadap audit delay karena pada tahun 2008 sedang terjadi krisis Eropa. Krisis tersebut terus berkembang menjadi krisis global dan berdampak ke perekonomian Indonesia. Perusahaan yang melakukan aktifitas ekspor akan mengalami penurunan permintaan ekspor dan penurunan harga komoditas sehingga pendapatan perusahaan menurun. Investor yang mengalami kesulitan likuidasi juga menarik aset yang dimiliki di Indonesia (deleveraging). Pembiayaan ekonomi juga sedikit terhambat karena melemahnya nilai tukar rupiah (Bank Indonesia, 2009). Pengaruh tersebut dapat mengakibatkan banyak perusahaan mengalami kerugian di tahun 2008. 


\section{Pengaruh Ukuran KAP terhadap Audit Delay}

Variabel ukuran KAP (SIZE) tidak berpengaruh terhadap audit delay (AUDLAY) sebab nilai signifikansinya lebih dari 0,05 (5\%) yaitu 0.215 (21,5\%). KAP yang berafiliasi dengan KAP Big Four memiliki reputasi yang baik dan dapat menyelesaikan pekerjaan audit dengan lebih efektif dan efisien sehingga dapat menyelesaikan audit dengan tepat waktu. Hasil penelitian ini menunjukkan bahwa ukuran KAP tidak berpengaruh terhadap audit delay. Alasannya adalah KAP selain KAP big four pun juga dapat mengaudit dengan cepat karena peraturan BAPEPAM-LK X.K.2 bahwa semua perusahaan yang terdaftar di BEI harus menyampaikan laporan keuangan yang telah diaudit pada bulan ketiga tahun berikutnya. Dengan demikian KAP big four non non big four dapat menyelesaikan laporan audit dengan tepat. Hasil penelitian ini mendukung hasil penelitian dalam negeri Kartika (2009), Febriyanti (2011), Utami (2006) serta penelitian dari luar negeri yaitu Hossain dan Taylor (1998), Ahmad and Abidin (2008), Carslaw dan Kaplan (1991) dan Modugu et.al (2012).

\section{Pengaruh Opini Auditor terhadap Audit Delay}

Variabel opini KAP(OPINI) tidak berpengaruh terhadap audit delay (AUDLAY). Hal ini tampak dari nilai signifikansi dibawah 0,05 (5\%) adalah 0,00. Sehingga dapat dikatakan bahwa $\mathrm{H}_{4}$ diterima dan $\mathrm{H}_{0}$ ditolah, artinya opini KAP berpengaruh terhadap audit delay. Hasil penelitian ini didukung oleh penelitian Utami (2006), Kartika (2009), Naimi, et al. (2010), dan Shukeri dan Islam (2012). Opini auditor menjadi salah satu penentu lamanya audit karena proses pemberian pendapat selain Unqualified Opinion melibatkan negosiai dengan klien, konsultasi dengan partner audit yang lebih senior atau staf teknis lainnya dan perluasan lingkup audit (Elliot, 1982 dalam Utami, 2006).

\section{Pengaruh Ukuran Komite Audit terhadap Audit Delay}

Variabel ukuran komite audit (ACSIZE) tidak berpengaruh terhadap audit delay (AUDLAY) karena nilai signifikansinya di atas 0,05 yaitu 0.344 . Komite audit dipilih oleh komite independen dan terkadang juga diketuai oleh komite independen. Oleh sebab itu komite audit tidak terlepas dari komite independen. Komite independen dapat berfungsi sebagai pengawas jalannya perusahaan dengan memastikan bahwa perusahaan tersebut sudah mematuhi prinsip-prinsip GCG yang sudah ditentukan. Prinsip tersebut antara lain transparansi, disklosure, akuntabilitas, kemandirian, dan keadilan yang berlaku di Indonesia. Hasil penelitian ini didukung oleh Shukeri dan Nelson (2011) dimana tidak ada pengaruh ukuran komite audit terhadap audit delay. 


\section{Pengaruh Jumlah Pertemuan Komite Audit dengan Audit Delay}

Variabel jumlah pertemuan komite audit (ACMEET) tidak berpengaruh terhadap audit delay (AUDLAY) karena nilai signifikansinya diatas 0,05 yaitu sebesar 0.698 $(69,8 \%)$.Pertemuan komite audit membahas masalah-masalah yang berkaitan dengan pelaporan keuangan. Salah satu tugas komite audit adalah membantu menyelesaikan masalah perusahaan yang berkaitan dengan laporan keuangan dan auditor eksternal. Namun, komite audit seringkali mendapat banyak hambatan dalam menjalankan tugas dan tanggung jawabnya untuk mendorong iklim GCG di perusahaan tempat mereka bertugas. Anggota komite audit yang bukan berasal dari eksekutif perusahaan belum cukup diberi keleluasaan dalam tugasnya dan kadang komite audit masih tunduk di bawah pengaruh dewan komisaris. Seharusnya Board of Directors dan Board of Commisaris memastikan bahwa eksternal auditor, internal auditor dan komite audit mempunyai akses terhadap informasi yang dimiliki perusahaan dengan syarat dapat menjaga kerahasiaan informasi yang didapat.

\section{DAFTAR PUSTAKA}

Asthana, S. 2012. Interpretation of Abnormal Audit Delay: Implications for Earnings Quality and Firm Value. American Accounting Association National Conference.

Ashton, R., dkk.1987. An Empirical Analysis og Audit Delay. Journal of Accounting Research Vol.25 No. 2 Autumn.

Bapepam-LK. 2002. Surat EdaranNomor : SE-02/PM/2002 tentang Pedoman Penyajian dan Pengungkapan Laporan Keuangan Emiten atau Perusahaan Publik. 2002. Siaran Pers Badan Pengawas Pasar Modal Tanggal 27 Desember 2002.

Carslaw, Charles, A.P.N., dan Steven, E.K.1991.An Examination of Audit Delay: Futher Evidence from New Zealand. Accounting Business Research Vol.22 No.85 pp 21-32.

Che-Ahmad, Ayoib, dan Shamharir, A. 2008.Audit Delay of Listed Companies: A Case of Malaysia. International Business Research (Online), Vol.1 No.4 (, diakses 20 Januari 2013).

Febrianty. 2011.aktor-Faktor yang Berpengaruh terhadap Audit Delay Perusahaan Sektor Perdagangan yang Terdaftar di BEI Periode 2007-2009. Jurnal Ekonomi dan Informasi Akuntansi. Vol.1No.3.

Ghozali, I. 2009. Apiklasi Analisis Multivariate dengan Program SPSS. Semarang: Badan Penerbit Universitas Diponegoro.

Hossain, M.A., dan Peter, J.T. 1998. An Examination of Audit Delay: Eviden from Pakistan.(Online). http://ssrn.com/abstract_id=2179389, diakses 4 Agustus 2013.

Ika, S.R., dan Nazli, A.M.G. 2012. Audit Committe Effectiveness and Timeliness of Reporting: Indonesian Evdence. Managerial Auditing Journal (Online) Vol.27 No.4, (www.emeraldinsight.com/0268-6902.htm, diakeses 16 Februari 2013).

Ikatan Akuntansi Indonesia (IAI). 2001. Standar Profesional Akuntan Publik Per 1 Januari 2001. Jakarta: Salemba Empat.

Ikatan Akuntansi Indonesia (IAI). 2012. Standar Akuntansi Keuangan Per 1 Juni 2012. Jakarta: Salemba Empat. 
Kartika, A. 2011. Faktor-Faktor yang Mempengaruhi Audit Delay di Indonesia. Jurnal Bisnis dan Ekonomi. Vol.16 No.1 pp 1-17.

Koroy, T.R. 2008. Pendeteksian Kecurangan Laporan Keuangan oleh Auditor Eksternal. Jurnal Akuntansi dan Keuangan Vol.10 No.1.

KNKG. 2006. Pedoman Umum Good Governance Indonesia. Jakarta: Mentri Koordinator Bidang Perekonomian.

Lambert, Tamara, A. 2007.Unintended Consequences Fillings: Do Change in Audit Delay Lead to Changes in Earning Quality? (Online), (http://aaahq.org/audit/midyear/08midyear/papapere/48_lambert_unintendedconsequences.pdf, diakses 19 Januari 2013).

Modugu, P.K., dkk. 2012. Determinants of Audit Delay in Nigerian Companies:Empirical Evidence. Research Journal off Financial and Accounting (Online), Vol.3.No.6, (http:/ /www.iiste.org/Journals/ index.php/RJFA/article/download/2400/2399,diakses 19 Januari 2013).

Mohamad, N., Mohamad, N. 2010.Corporate Governance and Audit Report Lag in Malaysia. AsianAcademy of Management Journal of Accounting and Finance (AAMJAF) Vol.6 No.2 pp 57-84.

Mumpuni, R. 2011. Analisis Faktor-Faktor yang Mempengaruhi Audit Delay pada Perusahaan NonKeuangan di Bursa Efek Indonesia Tahun 2006-2008. Skripsi tidak diterbitkan. Semarang: FE Universitas Diponegoro.

Sabeni, A. 2005. Peran Akuntan dalam Menegakkan Prinsip Good Corporate Governance pada Perusahaan di Indonesia Tinjauan Prespektif Teori Keagenan. Pidato Pengusulan Guru Besar Universitas Diponegoro.

Shukeri, S.N., dan M.D. Amirul, I. 2012.The Determinants of Audit Timeliness:Evidence from Malaysia. Journal of Applied Sciences Research Vol.8 No.7 pp 3314-3322.

Shukeri, S.N., dan Sherliza, P.N. 2011.Timeliness of Annual Audit Report: Some Emprical Evidence from Malaysia.(Online), (http://ssrn.com/abstract=1967284, diakses 16 Februari 2013).

Subekti, I., dan Novi, W. 2004.Faktor-Faktor yang Berpengaruh terhadap Audit Delay di Indonesia. Simposium Nasional Akuntansi VII.

Tuanakotta, Theodorus, M. 2010.Berfikir Kritis dalam Auditing. Jakarta: Salemba Empat.

Utami, W. 2006. Analisis Determinan Audit Delay Kajian Empiris di Bursa Efek Jakarta. Buletin Penelitian No.9.

Wening, N., dan Tas, R. 2001. Faktor-Faktor yang Mempengaruhi Ketepatan Waktu Pelaporan Keuangan:Studi Empiris di Bursa Efek Jakarta. Tesis tidak diterbitkan. Semarang: Universitas Diponegoro. 